\title{
Spiritual Realism as a Literary Category
}

\author{
Redkin Valery Alexandrovich ${ }^{1}$
}

Professor of Tver State University,

Tver, Russia.

(date of receiving: January, 2020; date of acceptance: April, 2020)

\begin{abstract}
The core of Russia's spirituality is its millennial Christian fold in its truly national, chosen by our ancestors of the Orthodox faith, with its collegiality, tolerance, humanity, openness to divine revelation. In our literary studies there is a search for a term to denote the method of portraying life, in which the spiritual world acts as the highest reality. The term spiritual realism, which means putting Christian ideals into artistic form, has proved to be the most productive. The features of spiritual realism can be found not only in the works of B. Zaitsev and I. Shmelev, but the V.Y. Shishkov, S.D. Drozhzhin, A.A. Akhmatova, N. With. Gumilev, Y. Kuznetsov, N. Rubtsov, V. Krupin and many other writers of the twentieth century and the classics of Russian literature century. The difference between spiritual realism and romanticism and traditional realism is revealed. In some contemporary works, the conflict is portrayed as a struggle of spirit and flesh. In this spiritual warfare is the formation of personality.
\end{abstract}

Keywords: Spiritual Realism, Realism, Romanticism, Christianity, Orthodoxy, Method, Stylistic Course, Postmodernism.

1. E-mail: synikolaeva@rambler.ru 


\title{
Духовный реализм как литературоведческая категория
}

\section{Редькин Валерий Александрович ${ }^{1}$}

Профессор, Тверский государственный университет,

\author{
Тверь, Россия.
}

(дата получения: январь 2020 г.; дата принятия: апрель 2020 г.)

\begin{abstract}
Аннотация
Сердцевиной духовности России является её тысячелетнее лоно христианства в его подлинно национальной, избранной нашими предками конфессии православия, с его соборностью, терпимостью, человеколюбием, открытостью Божественному откровению. В нашем литературоведении идет поиск термина для обозначения метода изображения жизни, при котором духовный мир выступает как высшая реальность. Термин духовный реализм, под которым понимается облечение христианских идеалов в художественную форму, оказался наиболее продуктивным. Черты духовного реализма можно обнаружить не только в творчестве Б. Зайцева и И. Шмелева, но и В.Я. Шишкова, С.Д. Дрожжина, А.А. Ахматовой, Н.С. Гумилева, Ю. Кузнецова, Н. Рубцова, В. Крупина многих других писателей XX века и классиков русской литературы XIX века. Выявляется отличие духовного реализма от романтизма и традиционного реализма. В ряде современных произведений конфликт рисуется как борьба духа и плоти. В этой духовной брани происходит формирование личности.
\end{abstract}

Ключевые слова: Духовный Реализм, Реализм, Романтизм, Христианство, Православие, Метод, Стилевое Течение, Постмодернизм.

1. E-mail: synikolaeva@rambler.ru 


\section{Введение}

После того, как были потеснены и подвергнуты критике в конце 80-х - 90-е годы концепции реализма, в основе которых лежал социальный аспект (критический реализм, социалистический реализм), стало неизбежно возвращение к поискам определения художественного метода на основе русской религиозно-философской и литературоведческой мысли начала ХХ века. Сердцевиной духовности России является её тысячелетнее лоно христианства в его подлинно национальной, избранной нашими предками конфессии православия, с его соборностью, терпимостью, человеколюбием, открытостью Божественному откровению. Вера в Бога, в существование иного мира опирается на живой религиозный опыт. С.Н. Булгаков считал, что у человека существует особый орган «религиозного видения» и подчеркивал: «Кто не хочет принять здесь единственно простой и естественной (но почемулибо для него метафизически недопустимой) гипотезы религиозного реализма, тот должен противопоставить ей теорию массовых галлюцинаций и иллюзий или же... «выдумки жрецов» (Булгаков 1994. 19). По его словам, в религиозном переживании дано «непосредственное касание мирам иным, ощущение высшей божественной реальности». Для человека верующего инобытие, духовная ипостась бытия не менее, а более реальна, чем видимая нам физическая материя, природный и социальный миры.

А.П. Черников ввел понятие «духовный реализм» для характеристики творчества И. Шмелёва, оттолкнувшись от шмелевского самоопределения романа «Пути небесные» как «духовного романа» (Черников 1995. 316). Автор этих строк попытался раскрыть черты духовного реализма в творчестве В.Я. Шишкова, С.Д. Дрожжина, А.А. Ахматовой, Н.С. Гумилева, Ю. Кузнецова, Н. Рубцова и других писателей, понимая под духовным реализмом «облечение христианских идеалов в художественную форму» (Редькин 1999. 3; Редькин 2000. 35; Редькин 2002. 3), М. М. Дунаев применил это определение к писателям, воплощающим духовную сферу бытия в пределах представлений 
«исторического православия» (Дунаев 2003. 7), А.М. Любомудров охарактеризовал духовный реализм Б. Зайцева и И. Шмелева, определив его как «строго христианскую духовность» (Любомудров 2003. 12), А.А. Андреев поставил вопрос о «духовном реализме русских классиков XIX века» (Андреев 1998. 23), А. В. Гулин пишет о духовном реализме Л.Н. Толстого (Гулин 2004. 145). С.Ю. Николаева, анализируя зачин романа Л.Н. Толстого «Воскресенье», подчеркивает, что он в «большей мере теологичен, как и образы реки или дверей... Мир Божий противопоставляется здесь миру человеческому» (Николаева 2013. 79). Своеобразие чеховской манеры он видит «не в плоском бытовизме, а в тонком сочетании реалистических и романтических тенденций, в филигранной поэтике диалога с романтиками, переосмыслении библейских и фольклорных сюжетов, святоотеческого наследия (Николаева 2013. 67). Термин начинают широко использовать молодые ученые. Но в теоретических построениях, связанных с понятием метода, продолжает доминировать социальный подход. Русская классическая литература продолжает определяться как литература критического реализма. В сознании литературоведов прочно укоренилась концепция В. Белинского «натуральной школы» и его оценка с этой точки зрения творчества Н.В. Гоголя. Но можно полностью согласиться с В. Зеньковским, что позиция Гоголя - это «приближение эпохи нового, свободного сближения культурного сознания с Церковью», «это целая программа построения культуры в духе Православия на основе «простора», т.е. свободного обращения ко Христу» (Зеньковский 2001. 175-176). Таким образом, в творчестве Н.В. Гоголя ярко проявился именно духовный реализм.

\section{Основная часть}

Сейчас в нашем литературоведении идет поиск термина для обозначения метода изображения жизни, при котором духовный мир выступает как высшая 
реальность. В этом смысле термины «мистический реализм», «метареализм», «религиозный реализм», «психологический реализм» имеют расширительное значение, а, скажем, выражения «пасхальный реализм», «духовная поэзия»напротив, слишком узкие понятия, предполагающее не светское, а чисто религиозное содержание. Не может удовлетворить и такая дефиниция, как «христианский реализм», так как в этом случае не учитывается национальная специфика, исчезает национальный образ мира, которые, несомненно, воплощаются в каждой национальной литературе. Совершенно непродуктивен термин «магический реализм», предложенный Ю. Боревым и О. Овчаренко и перенесенный ими из латиноамериканского художественного опыта на русскую почву. У Л. Леонова в «Пирамиде», Ю. Кузнецова в поэме «Путь Христа» и даже у М. Булгакова в «Мастере и Маргарите» не просто разрушается граница между реальностью фантастикой, их творчество - это не просто отражение коллективного мифологического сознания. Писатели опираются на духовный опыт русского народа как народа православного, переносят борьбу между добром и злом с земли на небо, в духовную сферу. О. Овчаренко признавал, что «Л. Леонов не сомневался в существовании дьявола, искренне верил в его распрю с Богом». Поэтому нельзя согласиться с тем, что более семидесяти лет большевизма вытравили из сознания русского человека религиозное мировоззрение, как считают некоторые критики. Свидетельством тому не только творчество И. Шмелева и Б. Зайцева, но и А. Ахматовой, В. Шишкова, М. Пришвина, В. Белова, В. Крупина, Л. Бородина, Н. Рубцова и многих других писателей XX века. К ним можно отнести слова Солженицына из его «Нобелевской лекции», передающие суть мироощущения, художника стоящего на позициях православия: «Один художник мнит себя творцом независимого духовного мира, и взваливает на свои плечи акт творения этого мира... Другой - знает над собой силу высшую и радостно работает маленьким подмастерьем под небом Бога...» (Солженицын 1989. 136). Большой вклад в 
изучение проблемы «христианство и литература» внесли национально ориентированные литературоведы В.Н. Захаров, В.В. Компанеец, И.А. Есаулов, Л.Ф. Алексеева, А.Б. Тарасов, Н.Ю. Желтова и мн. др., но вопрос о методе, когда художник в своем творчестве воплощает православное мировидение, остается открытым.

Следует признать, что термин «духовный реализм» весьма условен, как и большинство других терминов в литературоведении. Кто-то говорит о коммунистической духовности, кто-то о духовности самых различных религий и конфессий. Кто-то считает реальностью только вещественно-предметный мир и отрицает духовную реальность. Но в данном случае речь идет о русской национальной литературе, о традиции, которая признает существование духовной реальности и считает истинной только православную духовность. Так, Серафим Роуз разоблачает лжедуховность не только атеизма и язычества, но и христианских неправославных конфессий. «Жизнь большинства нынешних «христиан», - подчеркивает православный американский проповедник, -настолько пропитана эгоцентризмом и самодовольством, что какое-либо понимание смысла духовной жизни для них - за семью печатями; поэтому, когда они пытаются жить «духовной жизнью», то приходят только к иной форме самодовольства» (Роуз 1991. 190).

Духовный реализм предполагает православный тип мировосприятия художника и соответствующую систему ценностей. Что касается предмета изображения, то следует подчеркнуть, что круг тем не может быть ограничен: писатель может говорить как о духовной, так и о телесной, душевной жизни человека. Этот тезис звучит в книге А.М. Любомудрова: художник «не отвергает конкретную действительность, не чуждается социальных, психологических, этических, исторических аспектов, но дополняет их воссозданием духовной реальности» (Любомудров 2003. 235). Однако фактически этот ученый отдает приоритет произведениям на церковную и 
монастырскую тему. С нашей точки зрения, писатель православной ориентации воплощает черты духовного реализма не обязательно в произведениях, сюжетно связанных с жизнью монастырей, святых обителей и церкви. Православное мировосприятие может проявляться в произведениях на самые разнообразные темы: войны и мира, революции и реформ, личной судьбы и судьбы народа, семейной и общественной жизни, человека и природы, человека и космоса. При этом художественный мир произведения выстраивается на основе православной системе и иерархии ценностей и оценок.

Однако пределы использования термина «духовный реализм» остаются неопределенными, не поставлена проблема его соотношения с традиционными понятиями «реализм» и «романтизм». Нам представляется, что для выявления характерных черт духовного реализма необходимо вернуться к классификации П.Н. Сакулина, который предпочитал говорить о реализме и ирреализме, считая романтизм одним из видов ирреализма. «Реализму противостоит, в качестве полярности, ирреализм. - Подчеркивал он. - В его чистом виде ирреализм допускает, помимо конкретной действительности, существование «миров иных», a, следовательно, характеризуется ирреализмом мировосприятия и миропонимания. В глазах иррационалиста «миры иные» имеют неизменно большую цену, чем преходящая эмпирическая действительность» (Сакулин 1990. 154). Это и сближает духовный реализм с романтизмом. Чертами их общности, кроме иррационального начала, являются особая сердечность, приоритет духовных ценностей над материальными, а также такие элементы стиля, как повышенная роль эмоциональной окраски слова, широкое использование символа как окна в иной мир. Но, в отличие от романтизма, в искусстве духовного реализма нет двоемирия. И духовные сферы, и мир природы, и социальный мир - все объято Божьей волей. Это Божий мир. Субъективная позиция писателя здесь не может играть 
доминирующей роли, и писатель не стремится к пересозданию действительности, ибо твердой опорой для него является Священное писание, духовность, выработанная и накопленная Соборной Церковью. Здесь нет субъективно-оценочных элементов в авторской речи, пристрастия к фантастике, гротеску и романтической иронии. Писатель принимает действительность и стремится увидеть в ней Промысел Божий, он отвергает детерминизм, признавая свободу выбора человека, но не абсолютизирует ее. Отличает духовный реализм от романтизма и присущий ему элемент консерватизма, стремление сохранить духовные основы национального мира. Православному сознанию свойственен глубокий патриотизм. Утверждается не романтический идеал, а вполне конкретный, жизненный. Православная соборность противостоит романтическому индивидуализму.

По мысли Н. Бердяева, «творец-художник есть вместе с тем человек, духовное существо, несущий образ и подобие Божье, он же совершает нравственные и познавательные акты, он же верит и живет жизнью социальной» (Бердяев 1993. 330). Русские писатели, поднимающиеся к вершинам духовного реализма, насущные проблемы века: социальные, политические, исторические, нравственные преломили через призму своей веры или её поиска. Таковы романы И. Шмелева «Лето Господне» и «Пути небесные» о сложном пути к Богу и интимном приобщении к церковной жизни главных героев. Православие Шмелев называл купелью русской литературы, истинное искусство с его точки зрения глубоко религиозно, «стоит на Христе, на Боге и от Бога».

То же можно сказать о романах В. Шишкова «Угрюм-река» и «Емельян Пугачев». Это реализм с элементами романтизма, глубоким психологизмом, религиозно-философским осмыслением бытия. В одном из писем М. Горькому В.Я. Шишков писал: «Реализм... романтизм... символизм... Ведь это все формулы? А разве можно творить по формулам? Когда я пишу, могу ли я 
думать о том, реализм это или романтизм? Я знаю только один закон: писать надо правдиво» (Шишков 1956. 205). И рассматривать его творчество надо именно с этих позиций. В самой форме повествования В.Я. Шишков воплощает великую любовь к Божьему миру и падшему, греховному человеку, который стремится покаяться, очиститься и взмыть в небеса, но далеко не всегда ему это удается.

Главные ценности из мира внешнего, социального перемещаются во внутренний мир человека и у ряда поэтов XX века. Эти ценности не всегда доступны рациональному сознанию. Личность остается сокровенной, несет в себе некую тайну. Этим и привлекает к себе творчество Н. Гумилева и А. Ахматовой. В глубине их стиха мерцает непостижимый смысл бытия. По словам русского религиозного философа Б.П. Вышеславцева, предельная глубина человека закрыта «в значительной степени и для него самого» (Вышеславцев 1992. Т. 1: 66). И только в творчестве человек раскрывает глубину своей личности, «бездну своего сердца». По словам С. Булгакова, «Бог есть навеки неведомая, недоступная, непостижимая, неизреченная Тайна, к которой не существует никакого приближения» (Булгаков 1994. 91). Вот это ощущение тайны и составляет особенность духовного реализма. Тайны Бога, тайны мира, тайны человека. Создавая акмеистическую эстетику, Гумилев шел к принятию Бога и этических норм, санкционированных авторитетом православного христианства. «Поэзии и религия - две стороны одной и той же монеты. И та, и другая требует от человека духовной работы. Но не во имя практической цели (...), а во имя высшей, неизвестной им самим» (Гумилев 1990. 59-60). Хорошо знавший поэта К.В. Мочульский чутко уловил духовнорелигиозную природу акмеизма Н. Гумилева: «Символизм считал мир своим представлением, а потому иметь Бога не был обязан. Акмеизм поверил, и все отношение к миру сразу изменилось. Есть Бог, значит, есть и «иерархия в мире явлений», есть «самоценность» каждой вещи... Дерзания мифотворцев и 
богоборцев сменяются целомудрием верующего зодчего: «труднее построить собор, чем башню» (Цит. по: Гумилев 1990. 287).

Ярким явлением духовного реализма в поэзии XX века является творчество А.А. Ахматовой. Эта поэтесса в стремлении к исповедальности и предельной искренности воплощала в своем творчестве единство духа и плоти, земли и Неба, передавала ощущение реального существования ада и рая. В целом её творчество - это психосамоанализ, но не во фрейдистском смысле, а в значении постижения сущности Бога и первородного греха в человеке, истины, явленной в Откровении и собственном духовном опыте. Характерно, что на духовно-религиозные национальные традиции ориентирована и жанровая система поэзии Ахматовой. Широко используются ею такие формы лирики, как исповедь, проповедь, предсказание, молитва. В ряде стихотворений она непосредственно обращается к Богу: «Господи, помилуй нас», «Христос, помоги», «Боже, мир душе верни». В жанре молитвы поэт выражает свою глубокую веру в Пресвятую Троицу, безмерную Божественную Любовь, Царствие Небесное, решительно отвергает дьявольские искушения, искренне кается в своих грехах и выражает надежду, что в страдании душа обогатиться и спасется: «Дай ты мне молодость трудную. Столько печали в пути. Как же мне душу скудную Богатой тебе принести?»

В ряде современных произведений конфликт рисуется как борьба духа и плоти, пути проникновения и укоренения в душе греха. В этой духовной брани происходит формирование личности. Представителям духовного реализма в гносеологическом аспекте проблема «человек и мир» видится сложнее и иррациональнее, чем позитивистам. Они ставят не временные, а вечные вопросы о смысле жизни и предназначении человека. Объект их анализа совесть, стыд, вина, память. Их идеалы основаны на христианском миропонимании, взывающем к добру и справедливости. Трагическое начало заложено в основу бытия, ибо для человеческого сознания пути Господни 
неисповедимы, ибо силен сатана, ибо, чтобы приобщиться к Богу, приходится пройти путь страданий. Собственно в этом и заключается земное существование человека с редкими или ограниченными во времени периодами счастья жизни по Божьей воле, Божьей правде, прозрения Божьей истины. Так представлена суть бытия в романе-наваждении Л. Леонова «Пирамида», где выражена тревога перед угрозой гибели человечества. Такова суть истинно духовной концепции романа-эпопеи М. Шолохова «Тихий Дон». Для человека православного «мир не только творится, но и содержится словами Божьими, поэтому печать Божественной красоты и смысла неотъемлема от него» (Роуз 1991. 14).

В наше время ярким явлением духовного реализма в поэзии стала тетралогия Ю. Кузнецова «Путь Христа». В поэме утверждается духовная основа бытия. Суть событий передается в метафоре: «Молния духа в расселину времени бьет». Слова Христа - это духовная пища, вкушаемая народом. События, воплощающие духовную суть бытия, образ Христа - Сына Человеческого и Христа - Сына Божьего представлены как высшая реальность. Не случайно в тексте нагнетаются понятия миража, сна, грезы. Поэма - плод воображения автора, но не только, ибо сам мир, реальная действительность, по большому счету, плод творческого воображения Творца. По ассоциации с поэмой Мир воспринимается как творение Божье, то есть, как греза, мираж, фантазия. В поэме как бы сталкиваются Божественное творческое видение, сущностное, истинное, и дьявольское наваждение, которое пытается извратить, исказить истину. Поэт в своем произведении стремится к Божьей истине. Отмечая библейскую основу произведения, следует сказать о свободе воображения автора, о её фольклорности и свободе творческих ассоциаций автора. Поэт не скован традицией, он остается верен ассоциативно-метафорическому стилю, свойственному его творчеству в целом. Не учитывая этого, трудно понять основной смысл произведения. 
Чертами духовного реализма с разной степенью постижения исторического православия обладает творчество целого ряда поэтов православной ориентации Н. Карташовой, О. Гречко, Л. Патраковой, М. Аввакумовой и др. Продолжается стремление к созданию «религиозно обоснованного романа». Так, например, соединил современный роман с духовными жанрами Владимир Максимов. Христианство сквозная тема его творчества. Русская православную духовность утверждает в своих повестях Л. Бородин У этих писателей тоже можно найти черты духовного реализма.

В современном постмодернизме возникают тенденции разрушения национальной культуры. Этой тенденции противостоит реализм вообще и духовный реализм в частности. Поэтому вряд ли можно согласиться с мнением о том, что «реализм все более начинает являть усталость форм, исчерпанность образной системы, оскудение творческих идей» (Дунаев 2003. 3).

Ученый, богослов и филолог совершенно прав, когда утверждает, что только «в Православии, несущем в себе полноту Истины, обретаются единственно истинные критерии оценки всех явлений окружающей нас жизни. И всякого художника подстерегает грех искажения истины, если он отвергает сам религиозный подход к мироотображению». Но на основании того, что, с его точки зрения, «красота начинает откровенно служить дьяволу», что «сила эмоционального переживания отождествлялась с поэзией», он фактически отлучает от православной духовности почти всех русских классиков XIX и XX века: Л.Н. Толстого, Н.С. Лескова, А. Блока, А. Ахматову, Н. Гумилева, С. Есенина, Н. Клюева, Л. Леонова и др. Утверждения о том, что для Блока характерно «бесовидение», для Есенина - «бесовская тяга», а Гумилев «вторично распял Христа», не убеждают. Не следует отождествлять точку зрения автора и героя, даже лирического. Прямолинейная трактовка художественного текста неприемлема. Учение Л. Толстого - это одно, а его художественная практика - это совершенно другое. Божья искра таланта 
позволяет писателю вопреки догмам своего мировоззрения прорваться и прозреть истину Бога и сотворенного им мира. Если Христос говорил: «Я есмь путь» (Иоанн, 14, 6), то и Христова церковь - это путь к Богу, к истине, а не абсолютная истина, которой обладает только Творец. Больше того, М. Дунаев утверждает: «С точки зрения Высшей Истины мы не сумеем отыскать ничего нового, своего, «оригинального» ни у одного из истинно великих художников и писателей. В этом смысле, например, весь Достоевский вторичен. Как и преподобный Андрей Рублев. И Пушкин, и Гоголь, и Чехов» (Дунаев 2003. 51). Эта вторичность к воле и мудрости Всевышнего. Абсолютизируя Волю Господа, исследователь не учитывает специфику искусства, забывает, что художник личность со своей волей. Возникает противоречие с его собственной идеей сотворчества. Каждый художник к истине Бога идет по-своему пути. Вопрос в том, чтобы он не уходил от неё. Истинное творчество, по словам М. Дунаева, есть «соединение духовного стремления человеческой души к Творцу и излияние Божественной благодати, одухотворяющей творческую потенцию художника». Но как раз этим и отличается русская художественная классика! Что касается красоты, то здесь уместно привести слова митрополита Филарета, более двадцати лет возглавлявшего Русскую Православную Церковь за границей: «Христианство умеет ценить и любить красоту. И красоту в христианстве мы видим всюду: и в храмоздательстве, и в богослужении, и в музыке церковного пения, и в живописи - иконописи. При этом замечательно, что красоту в природе любили и ценили самые строгие наши подвижники, вполне отказавшиеся от мира. ... Истинная красота всегда возвышает, облагораживает, просветляет человеческую душу и ставит перед нею идеалы правды и добра. И никогда христианин не признает прекрасным то явление или произведение искусства, которое - хотя бы и в совершенном исполнении - не очищает и не просветляет душу человека, но опошляет и загрязняет её» (Филарет 1990. 40-41). 
Существует мнение о том, что «истинно религиозное искусство возможно лишь при соединении молитвенно-аскетического подвига с творчеством», и это соединение может быть достигнуто лишь «ценою совершенного смирения» (Дунаев 2003. 61). Действительно, классики русской литературы не обладали смирением. Они были активны и искали пути борьбы с силами зла в греховном, падшем мире. Но и Христос в этот мир пришел с мечом. Войны «во имя справедливости и восстановления порядка и правды - берутся христианским учением под защиту» (Филарет 1990. 46).

\section{Заключение}

Таким образом, следует отметить мощную традицию православного мировосприятия, свойственную русской литературе, и её интертекстуальность в отношении Библии и других книг Священного писания. Только обращаясь к этим проблемам можно всесторонне проанализировать основные тенденции литературного процесса и проникнуть в глубину художественного текста. У ряда писателей главные ценности из мира внешнего, социального перемещаются во внутренний мир человека. Эти ценности не всегда доступны рациональному сознанию. Этим и привлекает к себе внимание творчество И. Шмелёва и Б. Зайцева, В. Шишкова и Н. Гумилева, А. Ахматовой, Н. Тряпкина, В Крупина и Ю. Кузнецова. В глубине их строки явно ощутим мерцающий и непостижимый смысл бытия. Писатели, поднимающиеся к вершинам духовного реализма, насущные проблемы века: социальные, политические, исторические, нравственные преломили через призму своей веры или её поиска. И в этом отношении они оставались внутренне свободными художниками, несмотря на все цензурные рамки и идеологическое давление. 


\section{Литература}

1- Андреев А.А. (1998). Проблема духовного реализма в русской классической литературе XIX века // Русская литература: национальное развитие и региональные особенности. Екатеринбург: Изд-во «ЕГУ». С. 23-35.

2- Бердяев Н.А. (1993). О русских классиках. -М.: Изд-во «Высшая школа». 368 c.

3- Булгаков С.Н. (1994). Свет невечерний: Созерцания и умозрения. -М.: Изд-во «Республика». $415 \mathrm{c.}$

4- Вышеславцев Б. (1992). Значение сердияа в религии // Путь: Орган русской религиозной мысли. -М.: Без издательства. С. 56-74.

5- Гулин А.В. (2004). Лев Толстой и пути русской истории. -М.: Изд-во «Наследие». $251 \mathrm{c.}$

6- Гумилев Н.С. (1990). Письма о русской поэзии. -М.: Изд-во «Современник». $385 \mathrm{c}$.

7- Дунаев М.М. (2003). Православие и русская литература: В 6 т. -М.: Изд-во «Художественная литература». Т 5.509 с.

8- Зеньковский В.В. (2001). История русской философии. -М.: Изд-во «ЭКСМОПресс». 800 c.

9- Любомудров А.М. (2003). Духовный реализм в литературе русского зарубежья. Б.К. Зайщев. И.С. Шмелев. С-Петербург: Изд-во «Дмитрий Буланин».289 с.

10- Редькин В.А. (2002). А. Ахматова и Н. Гумилев и духовный реализм в русской поэзии XX века // Творчество Н. Гумилева и А. Ахматовой в контексте русской поэзии ХХ века. Тверь: Изд-во ТвГУ; «Золотая буква», С. 3-15.

11- Редькин В.А. (1999). Вячеслав Шишков: новый взгляд. Очерк творчества В. Шишкова. Тверь: Изд-во «ТОКЖИ». 152 с.

12- Редькин В.А. (2000). Духовный реализм в тверской поэзии XX века // Творчество Н. Гумилева и А. Ахматовой в контексте русской поэзии XX века. Тверь: Изд-во ТвГУ, С 3-15.

13- Николаева С.Ю. (2013). О символике пейзажа в «Воскресении» Л.Н. Толстого // Вестник Тверского государственного университета. Серия «Филология». № 10. Вып. 3. С. 78- 85 .

14- Николаева С.Ю. (2013). Балладное и лирическое начала в рассказе А.П. Чехова «Ведьма» // Вестник Тверского государственного университета. Серия «Филология». - 2013. - № 19. Вып. 4. С. 67- 74. 
15- Роуз, о. Серафим. (1991). Православие и религия будущего. -М.: Изд-во «Православная книга». 198 с.

16- Сакулин П.Н. (1990). Филология и культурология. -М.: Изд-во «Высшая школа». 240 с.

17- Солженицын А.И. (1989). Нобелевская лекциия // Новый мир. № 7. С.136.

18- Филарет, игумен. (1990). Конспект по Закону Божию. -М.: Без издательства. $140 \mathrm{c}$.

19- 18 Черников А.П. (1995). Проза И.С. Шмелева. Концепция мира и человека. Калуга: Изд-во «Калуж. обл. ин-т усовершенствования учителей». $341 \mathrm{c.}$

20- Шишков В.Я. (1956). Неопубликованные произведения. Воспоминания о В.Я. Шишкове. Письма. -Л.: Изд-во «Лениздат». 398 с.

\section{Bibliography}

1- Andreev A.A. (1998). Problema duhovnogo realizma v russkoj klassicheskoj literature $H I H$ veka // Russkaja literatura: nacional'noe razvitie i regional'nye osobennosti. Ekaterinburg: Izd-vo «EGU». S. 23-35.

2- Berdjaev N.A. (1993). O russkih klassikah. -M.: Izd-vo «Vysshaja shkola». 368 s.

3- Bulgakov S.N. (1994). Svet nevechernij: Sozercanija i umozrenija. -M.: Izd-vo «Respublika». $415 \mathrm{~s}$.

4- Vysheslavcev B. (1992). Znachenie serdca v religii // Put': Organ russkoj religioznoj mysli. -M.: Bez izdatel'stva. S. 56-74.

5- Gulin A.V. (2004). Lev Tolstoj i puti russkoj istorii. -M.: Izd-vo «Nasledie». $251 \mathrm{s.}$

6- Gumilev N.S. (1990). .Pis'ma o russkoj pojezii. -M.: Izd-vo «Sovremennik». 385 s.

7- Dunaev M.M. (2003). Pravoslavie i russkaja literatura: V 6 t. -M.: Izd-vo «Hudozhestvennaja literatura». T 5. $509 \mathrm{~s}$.

8- Zen'kovskij V.V. (2001). Istorija russkoj filosofii. -M.: Izd-vo «JeKSMO-Press». $800 \mathrm{~s}$.

9- Ljubomudrov A.M. (2003). Duhovnyj realizm v literature russkogo zarubezh'ja. B.K. Zajcev. I.S. Shmelev. S-Peterburg: Izd-vo «Dmitrij Bulanin».289 s.

10- Red'kin V.A. (2002). A. Ahmatova i N. Gumilev i duhovnyj realizm v russkoj pojezii $H H$ veka // Tvorchestvo N. Gumileva i A. Ahmatovoj v kontekste russkoj pojezii HH veka. Tver': Izd-vo TvGU; «Zolotaja bukva», S. 3-15.

11- Red'kin V.A. (1999). Vjacheslav Shishkov: novyj vzgljad. Ocherk tvorchestva $V$. Shishkova. Tver': Izd-vo «TOKZhI». 152 s. 
12- Red'kin V.A. (2000). Duhovnyj realizm v tverskoj pojezii HH veka // Tvorchestvo N. Gumileva i A. Ahmatovoj v kontekste russkoj pojezii HH veka. Tver': Izd-vo TvGU, S 3-15.

13- Nikolaeva S.Ju. (2013). O simvolike pejzazha v «Voskresenii» L.N. Tolstogo // Vestnik Tverskogo gosudarstvennogo universiteta. Serija «Filologija». - № 10. Vyp. 3. S. $78-85$.

14- Nikolaeva S.Ju. (2013). Balladnoe i liricheskoe nachala v rasskaze A.P. Chehova «Ved'ma» // Vestnik Tverskogo gosudarstvennogo universiteta. Serija «Filologija». - 2013. - № 19. Vyp. 4. S. 67- 74.

15- Rouz, o. Serafim. (1991). Pravoslavie i religija budushhego. -M.: Izd-vo «Pravoslavnaja kniga». $198 \mathrm{~s}$.

16- Sakulin P.N. (1990). Filologija i kul'turologija.-M.: Izd-vo «Vysshaja shkola». $240 \mathrm{~s}$.

17- Solzhenicyn A.I. (1989). Nobelevskaja lekcija // Novyj mir. № 7. S.136.

18- Filaret, igumen. (1990). Konspekt po Zakonu Bozhiju. -M.: Bez izdatel'stva. $140 \mathrm{~s}$.

19- Chernikov A.P. (1995). Proza I.S. Shmeleva. Koncepcija mira i cheloveka. Kaluga: Izd-vo «Kaluzh. obl. in-t usovershenstvovanija uchitelej». $341 \mathrm{s.}$

20- Shishkov V.Ja. (1956). Neopublikovannye proizvedenija. Vospominanija o V.Ja. Shishkove. Pis'ma. -L.: Izd-vo «Lenizdat». 398 s.

\section{HOW TO CITE THIS ARTICLE}

Редькин В. А. (2020). Spiritual Realism as a Literary Category. Issledovatel'skiy Zhurnal Russkogo Yazyka i Literatury, 8(2), 6986.

DOI: $10.29252 /$ iarll.16.73

URL: http://journaliarll.ir/index.php/iarll/article/view/128

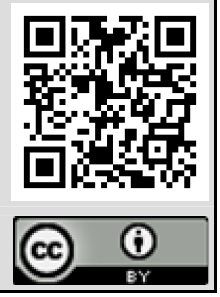


واقع گرايى معنوى بهعنوان مقولهُ ادبياتشناسى

\author{
والرى آلكساندرويج ردكين'

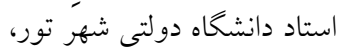 \\ تور، روسيه.

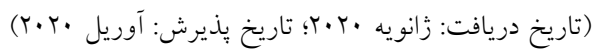

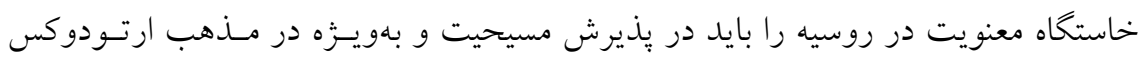

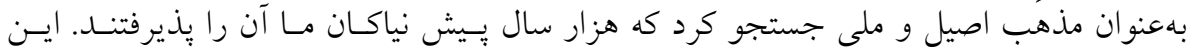

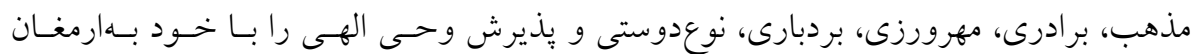

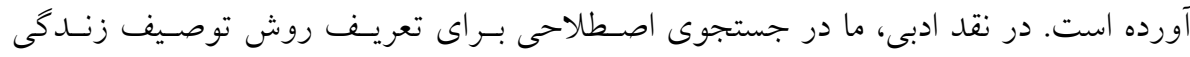

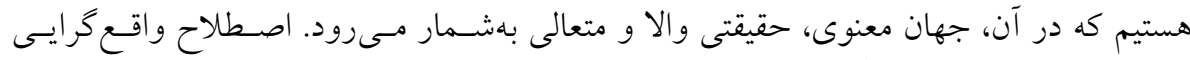

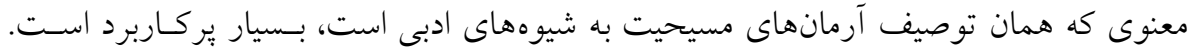

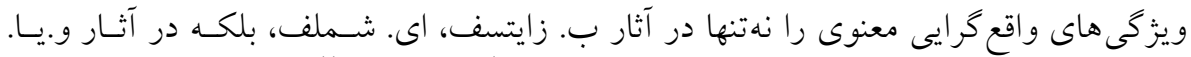

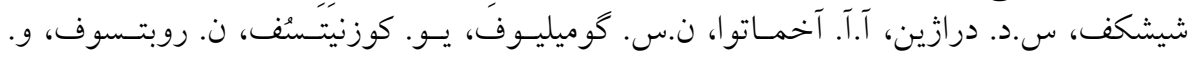

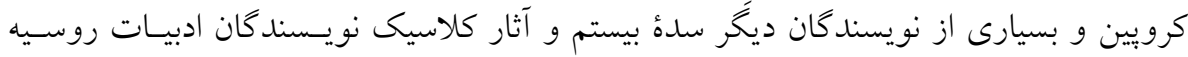

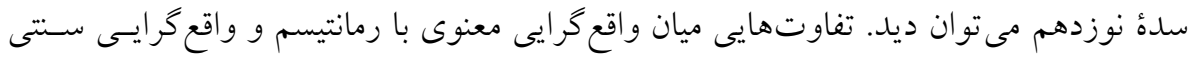

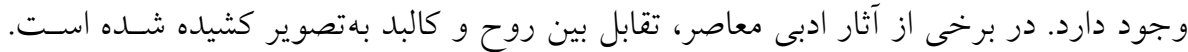

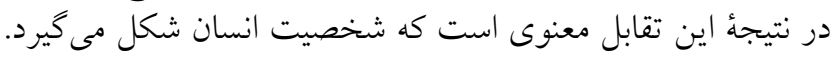

وازگًان كليدى: واقع گر ايى معنوى، واقع گرايى، رمانتيسم، مسيحيت، ارتودوكس، روش، سـبك

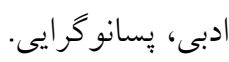

